\title{
MIĘDZY KRYZYSEM A ROZWOJEM. OGÓLNOPOLSKIE SYMPOZJUM DYDAKTYKÓW KOMPARATYSTYKI, TORUŃ, 30-31 MARCA 2016 ROKU
}

\author{
ADAM F. KOLA ${ }^{1}$, MARCIN WOŁK ${ }^{2}$ \\ (Uniwersytet im. Mikołaja Kopernika w Toruniu)
}

Trzeci doroczny zjazd Polskiego Stowarzyszenia Komparatystyki Literackiej (pierwszy odbył się w Pobierowie k. Szczecina w 2014 roku, drugi w Warszawie w 2015), przygotowany we współpracy z Pracownią Komparatystyki Literacko-Kulturowej Uniwersytetu Mikołaja Kopernika, odbył się w dniach 30-31 marca 2016 roku w Toruniu. Spotkanie zostało szczegółowo sprofilowane i dotyczyło dydaktyki komparatystyki w Polsce. Celem spotkania było rozpoznanie stanu dyscypliny z perspektywy dydaktycznej, jak również naszkicowanie mapy polskich studiów komparatystycznych. Już na wstępie trzeba powiedzieć, że cele te udało się zrealizować, chociaż nie wszystkie ośrodki akademickie były reprezentowane. Spotkanie pokazało złożony i wielowymiarowy obraz polskiej edukacji akademickiej w zakresie komparatystyki.

Punktem wyjścia i zarazem wstępem do zaproszenia na konferencję uczyniliśmy jako jej organizatorzy konstatację, która jeszcze parę lat temu brzmiałaby ryzykownie, a dziś jest po prostu optymistyczna - że mianowicie komparatystyka literacka i kulturowa w Polsce mają się dobrze. Tak można by rozpocząć esej o kondycji badań porównawczych w naszym kraju, pokazując wskaźniki owego pozytywnego stanu rzeczy - publikacje, konferencje, instytucje. Zarazem jednak wszyscy wiemy, że spora część otoczenia społeczno-politycznego stara się dezawuować znaczenie humanistyki jako takiej, uczelnie przeżywają trudności związane $\mathrm{z}$ niżem demograficznym i ograniczeniami finansowymi, sytuacja geopolityczna zaś (a ostatnio także wewnętrzna) nie sprzyja studiom międzykulturowym.

\footnotetext{
1 E-mail Address: adamkola@umk.pl

2 E-mail Address: wolkmarc@umk.pl
} 
Na takiej osi między samozadowoleniem a syndromem oblężonej twierdzy zaproponowaliśmy rozpięcie dyskusji o stanie dydaktyki komparatystyki w Polsce.

W odróżnieniu od dyskusji dotyczących komparatystyki jako dyscypliny ściśle naukowej - ogniskujących uwagę na badaniach - organizatorów i uczestników toruńskiej konferencji interesowało nauczanie komparatystyki na uniwersytetach w naszym kraju. Taka działalność w coraz większym stopniu staje się udziałem polskiej komparatystyki (rozwój!), wiążąc się zarazem z ogromnymi problemami (kryzys...), a nie stanowił dotąd istotnego pola namysłu. Coraz większa liczba ośrodków akademickich w Polsce oferuje specjalności, kursy lub osobne studia komparatystyczne. Odbywa się to $\mathrm{w}$ instytucjonalnych ramach polonistyki lub poza nimi - na anglistykach, germanistykach, slawistykach, niekiedy zaś kursy literatury porównawczej lub podobne tworzone są od podstaw w oparciu o wielokierunkowe kompetencje poszczególnych nauczycieli akademickich. Ta zmiana sytuacji w Polsce - powstawanie kolejnych ośrodków komparatystycznych i rozwój istniejących, rozszerzanie komparatystycznej oferty dydaktycznej, postępująca instytucjonalizacja badań porównawczych - stanowi wystarczającą przesłankę, by się nad zachodzącymi zmianami zastanawiać, by wymieniać się doświadczeniami. Jesteśmy bowiem przekonani, że - wbrew neoliberalnej narracji nakazującej w łonie Akademii niczym niepohamowaną konkurencję, czytaj: walkę o studenta to dzięki współpracy, wzajemnemu wsparciu i koordynacji działań w ramach tej wciąż niewielkiej dyscypliny, uda się ją ustabilizować i skierować w stronę, która pozwoli na jej pełny rozkwit. Również toruńskie spotkanie wynikło z przekonania, że praca na rzecz dobra wspólnego może przynieść korzyści wszystkim.

Zaproponowano kilka pól problemowych, które w różnym stopniu zostały wypełnione przez uczestników spotkania. Chodziło o krytyczny namysł nad praktykami dydaktycznymi, drogami rozwoju kierunków, specjalizacji i innych form nauczania, programami studiów I i II stopnia, elementami komparatystyki na studiach III stopnia, jakością kształcenia na komparatystyce, polityką edukacyjną w zakresie komparatystyki, lokalnymi odpowiedziami na globalne trendy akademickie, możliwościami wspólnej promocji dyscypliny w kraju, wreszcie - rolą Polskiego Stowarzyszenia Komparatystyki Literackiej jako koordynatora czy platformy takich działań.

Dwudniowa konferencja przybrała roboczy i warsztatowy charakter, podczas którego nie tylko poszczególne prezentacje były ważne, lecz również, a nawet przede wszystkim dyskusje i swobodna wymiana doświadczeń. Było to bowiem spotkanie praktyków komparatystycznej edukacji, choć odbywającej się w rozmaitych ramach instytucjonalnych.

Konferencję otworzył prodziekan Wydziału Filologicznego UMK, Maciej Wróblewski, pomysłodawca powołania zarówno Pracowni Komparatystyki Literacko-Kulturowej na tej uczelni, jak i kierunku studiów - komparatystyki literacko-kulturowej. Zwrócił on uwagę na związane zarówno z badaniami porównawczymi, 
jak i dydaktyką kwestie rosnącej roli kultury popularnej i rozwoju studiów kulturowych.

Wystąpienia pierwszego dnia koncentrowały się na ogólniejszych kwestiach problemowych oraz subdyscyplinarnych $\mathrm{w}$ dydaktyce komparatystyki, zaś panel dyskusyjny i prezentacje dnia drugiego dotyczyły nauczania komparatystyki w poszczególnych ośrodkach akademickich w Polsce. W wielu wystąpieniach powracały jednak te same problemy.

Dariusz Pniewski (Uniwersytet Mikołaja Kopernika) mówił o tradycyjnej i ponowczesnej ekfrazie w perspektywie edukacji. Przekonywał, że nie zawsze to, co istotne $\mathrm{z}$ punktu widzenia badań naukowych, musi być użyteczne $\mathrm{w}$ dydaktyce. Wskazał na potrzebę wykorzystywania perspektywy komparatystycznej już na etapie edukacji szkolnej, do czego problematyka ekfrazy doskonale się nadaje, czyni przy tym zajęcia i lekcje bardziej atrakcyjnymi i interesującymi dla odbiorców. Obie te kwestie - obecność komparatystyki w szkole i troska o atrakcyjność naszego przekazu - niech stanowią zadanie dla wszystkich komparatystów. Lidia Wiśniewska (Uniwersytet Kazimierza Wielkiego) zajęła się niezbywalnością perspektywy polonistycznej w komparatystycznej praktyce dydaktycznej w Polsce, jak również pożytkami płynącymi z porównawczego mitoznawstwa. Zwróciła też uwagę na kwestię czysto praktyczną, tj. na formę prowadzonych zajęć komparatystycznych (ćwiczenia, konwersatorium, wykład). Podobnym tropem podążyła Agnieszka Smaga (Uniwersytet Kardynała Stefana Wyszyńskiego), która pokazała, że komparatystyka może mieć - i w przypadku komparatystyki mediów na UKSW ma - wymiar praktyczny. Komparatystyka (medialna, digitalna) ma tu wymiar utylitarny, zmierza w stronę humanistyki cyfrowej i wyrabiania u studentów praktycznych umiejętności i kompetencji w tym zakresie. Zresztą także drugi dzień pokazał wyraźnie, że aspekt praktyczny, również w kategoriach ekonomicznych i atrakcyjności absolwentów na rynku pracy, staje się istotnym elementem polskiej edukacji komparatystycznej. Także Adam Regiewicz (Akademia im. Jana Długosza), wychodząc od diagnozy kryzysu studiów polonistycznych, mówił o konieczności wyjścia naprzeciw zdigitalizowanemu światu. Dokonująca się zmiana paradygmatu kulturowego sprawia, że liczą się już nie tradycyjne kompetencje filologiczne, lecz umiejętność poruszania się w rzeczywistości cyfrowej. $\mathrm{W}$ jaki sposób filologia ma sobie z tym poradzić? Referent wyróżnił dwa rodzaje odpowiedzi uczelni na ten problem: albo próbują wychodzić naprzeciw oczekiwaniom młodych ludzi i włączać nowe media w programy tradycyjne („polonistyka cyfrowa"), albo też, zwrócone wstecz, okopują się na zajmowanych pozycjach, przejawiając coś, co Regiewicz nazwał „agresywną nostalgią za innymi czasami”. Jego propozycja stara się łączyć obie te perspektywy, proponując dobrze zakorzenioną $\mathrm{w}$ literaturoznawstwie strategię czytania kontekstowego, przy czym kluczowy miałby być kontekst otaczającego nas świata. Pierwszy panel zamykało wystąpienie Rafała Toczki (UMK), filologa klasycznego, dla którego optyka kom- 
paratystyczna - również w dydaktyce - jest oczywista. Z tej perspektywy można wymienić kilka możliwych propozycji edukacyjnych (ale i badawczych), by wskazać tylko na możliwość nauczania przez recepcję, obecność kultur i literatur antycznych we współczesnej kulturze popularnej czy studia prawdziwie globalne w ramach filologii klasycznej (np. w wersji zaproponowanej przez Martina L. Westa, który omawiał wpływ tradycji antycznych na literatury basenu Morza Śródziemnego). To, co łączyło wszystkie te wystąpienia, to m.in. przekonanie o konieczności czynienia programów studiów humanistycznych bardziej atrakcyjnymi i przystępnymi dla studentów, do tego zaś podejście komparatystyczne doskonale się nadaje.

Drugi panel poświęcony był powiązaniom studiów regionalnych z komparatystyką. Anna Branach-Kallas (UMK) przedstawiła konkretne programy studiów anglistycznych, w ramach których dzięki perspektywie postkolonialnej wprowadza się tematy globalne i teksty wykraczające poza kanon literatury anglosaskiej. Wskazała również konkretne metody i pomoce dydaktyczne, które ułatwiają studentom odbiór tego rodzaju treści, jak np. myślenie za pomocą mapy. Beata Waligórska-Olejniczak (Uniwersytet im. Adama Mickiewicza) z kolei sięgnęła po przykład studiów dwujęzycznych, w ramach których prowadzone są zajęcia z komparatystyki literacko-kulturowej nie tylko - w tym konkretnym przypadku na tradycyjnej filologii rosyjskiej, lecz również na rosyjsko-angielskiej i rosyjsko-ukraińskiej. Waligórska-Olejniczak zwróciła wszakże uwagę na problem, który w toku dyskusji wracał wielokrotnie, tzn. na narzuconą odgórnie konieczność redukcji liczby godzin zajęć komparatystycznych na wielu kierunkach, gdzie perspektywa porównawcza jest tylko pewnego rodzaju dodatkiem czy poszerzeniem podstawowego programu studiów. Wreszcie zamykający ten panel Adam Kola (UMK) mówił o tym, jak dydaktyka komparatystyki funkcjonuje na studiach slawistycznych/bałkanistycznych, zwłaszcza w sytuacji zmiany paradygmatycznej. Dawny sposób uprawiania slawistyki w duchu XIX-wiecznego słowianofilstwa, z naciskiem na pokrewieństwa językowe, odchodzi do lamusa i jest zastępowany przez studia regionalne, w których liczą się realne wpływy i zależności w obrębie np. Europy Środkowej (już nie tylko słowiańskie, ale również np. węgierskie, niemieckie czy żydowskie) czy Bałkanów (z Albańczykami, Rumunami, Turkami czy Grekami, bez których nie da się zrozumieć tego regionu, a co za tym idzie - uczyć o nim studentów). Wystąpienia te pokazały, że dydaktyka komparatystyki odbywa się również poza wyróżnionymi specjalnościami czy kierunkami, które mają porównanie $\mathbf{w}$ nazwie, że obecna jest $\mathrm{w}$ wielu innych jednostkach naukowo-dydaktycznych, zaś sami komparatyści zmagają się ze słabościami instytucjonalnymi swojej dyscypliny w polskim świecie akademickim. Potrzebna jest praca na rzecz wzmocnienia komparatystyki, nie tylko w wymiarze naukowym, lecz i dydaktycznym, praca na rzecz budowania renomy tej dziedziny i poprawy jej miejsca w polskim dyskursie humanistycznym. 
Dzień pierwszy zakończyło walne zebranie Polskiego Stowarzyszenia Komparatystyki Literackiej, w trakcie którego wybrano nowe władze, oraz wspólna kolacja.

Drugi dzień sympozjum został $\mathrm{w}$ całości poświęcony na przedstawienie poszczególnych komparatystyk $\mathrm{w}$ Polsce $\mathrm{z}$ punktu widzenia ich programów dydaktycznych i pomysłów na studia jako takie. Oczywiście już wystąpienia dnia pierwszego zawierały takie elementy, prezentowały się bowiem ośrodki bydgoski, warszawski (UKSW), częstochowski, poznański (rusycystyka) czy toruński (filologia klasyczna, anglistyka i bałkanistyka). Drugi dzień w formule otwartego panelu dyskusyjnego sprzyjał jednak nie tylko prezentacji założeń własnych projektów edukacyjnych, ale nade wszystko - wymianie doświadczeń i rozbudowanej dyskusji. Ewa Szczęsna zaprezentowała działającą jako specjalność w ramach polonistyki, komparatystykę na Uniwersytecie Warszawskim, wskazując na zachodzące $\mathrm{w}$ jej ramach zmiany - od klasycznych studiów literaturoznawczych w stronę komparatystyki intermedialnej i intersemiotycznej. Jakub Czernik z Uniwersytetu Jagiellońskiego zaprezentował nie tylko historię tamtejszej komparatystki, ale również jej stan dzisiejszy, w tym wciąż mocne zakorzenienie $\mathbf{w}$ ramach studiów polonistycznych. Jednocześnie zwrócił uwagę, że elementy komparatystyki obecne są także na innych kierunkach studiów prowadzonych na UJ, w tym również tych skierowanych do studentów zagranicznych. Marcin Wołk przedstawił historię komparatystyki literacko-kulturowej na UMK, czyli „toruńskiego eksperymentu". Kluczowym elementem tego projektu jest bowiem odejście od polonistyki jako bazy dla komparatystyki i stworzenie jej - jako osobnego kierunku studiów pierwszego stopnia - $\mathrm{w}$ oparciu o dyscyplinarne i osobowe zasoby całego Wydziału Filologicznego. Ten głos został uzupełniony przez wystąpienie studentek tego kierunku, Natalii Dobrzeleckiej i Kingi Mądraszewskiej, które opowiedziały, jak z perspektywy studenckiej i praktycznej wyglądają studia komparatystyczne, z jakimi trudnościami - niekiedy trywialnymi, lecz jakże istotnymi (jak np. trudność ułożenia sobie planu zajęć) - wiąże się studiowanie kierunku o bardzo dużej liczbie zajęć do wyboru.

Z kolei Marta Skwara z Uniwersytetu Szczecińskiego zaprezentowała nowy kierunek, w którym jądrem komparatystyki staje się translatologia, a nacisk położono - ponownie - na praktyczny i rynkowy wymiar studiów. Warte podkreślenia jest, że chodzi tu nie o przekład pojmowany tradycyjnie, ale właśnie komparatystycznie, dlatego program tych studiów odnosi się zarówno do przekładu inter-, jak i intralingwistycznego, interkulturowego czy intermedialnego. Ewa Łukaszyk z Wydziału Artes Liberales UW skupiła uwagę na elementach nowoczesnej, światowej komparatystyki w ramach elitarnych, międzynarodowych studiów doktoranckich, uwypuklając również praktyczne wymagania i oczekiwania studentów (np. e-learning czy inne formy studiów na odległość). Zwróciła też uwagę na fakt, że studia doktoranckie rządzą się szczególną logiką - doktoranci mają własne zaplecze intelektualne, doświadczenia, gotowe projekty badawcze itd. Co więcej, 
studia te $\mathrm{w}$ jej ośrodku odbywają się $\mathrm{w}$ języku angielskim, zaś instytucja macierzysta ułatwia ambitne przedsięwzięcia, ale i wymaga dużej aktywności naukowej. Sam program odnosi się do założeń humanistyki transkulturowej. Wreszcie ostatnie wystąpienie, Łukasza Musiała (UAM), dotyczyło projektu studiów z zakresu literatury światowej, studiów, których pierwszy cykl dydaktyczny ma się rozpocząć dopiero $w$ roku akademickim 2016/17. Było to przedstawienie założeń nowocześnie rozumianej komparatystyki jako literatury światowej (czy raczej - literatur świata) w duchu nadanym temu pojęciu przez Davida Damroscha. Ideą jest nauczenie studentów nowoczesnych sposobów czytania, umiejętności odnajdywania się we współczesnym, transkulturowym i zglobalizowanym świecie. Pod względem organizacyjnym i kadrowym projekt poznański zakorzeniony jest $z$ jednej strony w Pracowni Pytań Granicznych, z drugiej - w neofilologiach (germańskiej, angielskiej), nie zaś w polonistyce, co również jest jego cechą wyróżniającą.

Podsumowaniem panelu była długa i owocna dyskusja, która pozwoliła nie tylko skonfrontować ze sobą poszczególne projekty i pomysły, ale też wskazać ich punkty wspólne i rozbieżności. Umożliwiła ona zarysowanie konturów mapy polskiej komparatystyki widzianej z perspektywy praktyki edukacyjnej. Warto wskazać kilka stale powracających w dyskusji wątków, przy okazji których ujawniły się odmienności optyk, tradycji i podejść do dydaktyki komparatystycznej:

(1) kwestia odrębności studiów komparatystycznych: komparatystyka rozwijana jako wariant programu studiów polonistycznych vs. inne wzory (zakładanie nowych kierunków studiów opartych na neofilologiach lub tworzonych zupełnie od podstaw);

(2) cele i profile kształcenia: modele studiów o charakterze czysto akademickim vs. studia praktyczne;

(3) problem fundamentów metodologicznych: dydaktyka komparatystyki pomyślana jako próba przekazania sumy poszczególnych literatur narodowych vs. różnego rodzaju projekty literatury światowej czy humanistyki transkulturowej; komparatystyka literaturocentryczna vs. zorientowanie na translatorykę, humanistykę cyfrową czy nowe media; klasyczne studia oparte na kanonie euroatlantyckim vs. wychodzenie poza obszary euroamerykańskie w stronę komparatystyki planetarnej.

Oczywiście istnienie tych rozbieżności nie jest niczym złym, ich lista pokazuje bowiem pośrednio, że oferta porównawczych studiów humanistycznych jest w Polsce całkiem bogata i zróżnicowana. Niezależnie też od różnic, wiele spraw zaprząta głowy wszystkich dydaktyków komparatystyki:

(4) praktyczne problemy dydaktyczne ze wskazaniem na różnego rodzaju rozwiązania metodyczne;

(5) brak rozpoznawalnej marki komparatystyki i związany z tym opór części środowiska akademickiego przeciwko samodzielności dyscyplinarnej badań porównawczych czy odrębności dydaktyki komparatystycznej; 
(6) roztapianie się komparatystyki w innych dyscyplinach „parasolowych”, takich jak filologia, polonistyka, literaturoznawstwo, kulturoznawstwo, translatologia, które jest paradoksalnym rezultatem upowszechnienia się myślenia porównawczego we współczesnej humanistyce.

Drugi dzień konferencji zakończyła prezentacja monograficznego numeru czasopisma „Litteraria Copernica” $(2015$, nr 2) pt. Pożytki z porównania, zredagowanego przez piszących te słowa, oraz wykład z serii seminaryjnej Pracowni Komparatystyki Literacko-Kulturowej UMK Pogranicza - różnice - relacje zatytułowany Poetyka w świecie tekstów wieloznakowych, który wygłosiła Ewa Szczęsna.

Jako podsumowanie tego sprawozdania i dowód na to, że dyskusja wokół spraw dydaktycznych była i jest potrzebna, niech posłuży propozycja uczestników sympozjum, by w niedalekiej przyszłości (w roku 2018) spotkać się ponownie i kolejny raz zastanowić się nad problemami edukacji komparatystycznej w Polsce. 
